Asian J. Med. Biol. Res. 2018, 4 (1), 7-13; doi: 10.3329/ajmbr.v4i1.36815

\author{
Asian Journal of \\ Medical and Biological Research \\ ISSN 2411-4472 (Print) 2412-5571 (Online) \\ www.ebupress.com/journal/ajmbr
}

\title{
Article \\ Phytochemical screening and antifungal activity of Chromolaena odorata extracts against isolate of Phytophthora megakarya using agar-well diffusion method
}

\author{
Adeyemo I Adeyemi ${ }^{1}{ }^{*}$, Omotunlese I Vincent ${ }^{1}$ and Oni M. Olujenyo ${ }^{2}$ \\ ${ }^{1}$ Ondo State University of Science and Technology, Okitipupa, Ondo State, Nigeria \\ ${ }^{2}$ Adeleke University, Ede, Osun State, Nigeria
}

*Corresponding author: Adeyemo I Adeyemi, Ondo State University of Science and Technology, Okitipupa, Ondo State, Nigeria. Phone: +2348035671847; E-mail: adeyemiyourfriend @ gmail.com

Received: 02 January 2018/Accepted: 26 March 2018/ Published: 29 March 2018

\begin{abstract}
In-vitro study of Chromolaena odorata extracts was determined against isolated Phytophthora megakarya for the purpose of investigating the antifungal activity of ethanolic, cold-water and warm-water extracts of the medicinal plant against Phytophthora megakarya. Their antifungal effects were assessed with agar-well diffusion methods. Phytochemical screening and minimum inhibitory concentrations of the extracts were also determined. A qualitative phytochemical analysis of the extracts showed the presence of biologically active constituents such as flavonoids, phenols, tannins, sterols, amino acid and glycosinulate. Results showed that antifungal effects of Chromolaena odorata against Phytophthora megakarya were most efficient by ethanolic extracts, followed by extract of cold-water while hot water extract had no visible antifungal effect. Zones of clearance range from $15.00 \mathrm{~mm}$ to $32.00 \mathrm{~mm}$ using ethanolic extractions with concentrations from $1 \%$ to $5 \%$ while zones of clearance using cold water extract was from $5.00 \mathrm{~mm}$ to $30.00 \mathrm{~mm}$ with varying concentrations of $1 \%$ to $5 \%$. The negative control using sterile distilled water showed no inhibitory effect on Phytophthora megakarya while $41.00 \mathrm{~mm}$ zone of clearance was observed in the positive control test using Metalaxyl and cuprous oxide-containing synthetic fungicide. This study provides a scientific confirmation of the use of Chromolaena odorata against cocoa pod infections by some local farmers.
\end{abstract}

Keywords: antifungal; extracts; cocoa pod; agar well; concentrations

\section{Introduction}

Phytophthora spp. is a cosmopolitan genus of Oomycete obligate plant pathogens containing approximately 60 described species (Erwin and Ribeiro, 1996). Phytophthora species attack a wide range of plants and are responsible for some of the world's most destructive plant diseases - examples include the European potato famine of the 19th century caused by P. infestans (Bourke, 1964). Phytophthora diseases have been well studied in the temperate regions of the world. However, Phytophthora diseases are very common throughout the wet tropical regions of the world and cause significant diseases losses in many tropical fruit crops in the form of root rots, collar rots, stem cankers, leaf blights and fruit rot. For example, P. palmivora alone causes a myriad of severe diseases on many different crops including: black pod of cocoa; root, stem and fruit rot of pawpaw; root rot and blight of citrus; bud rot in palms; black stripe in rot in durian.

Phytophthora megakarya appears to be confined to West Africa (Zentmeyer, 1987), where it is the most common species of Phytophthora causing black pod disease of cocoa. Theobroma cacao (cocoa) is indigenous to the New World and ranges from southern Mexico in the north to Brazil and Bolivia in the south. The centre of origin is considered to be the basin of the Upper Amazon (Wood, 1975). This would indicate that if $P$. megakarya is only present in West Africa, it must have another host that is as yet undetermined and cocoa is a new host. Alternatively, P. megakarya may have co-evolved with cocoa in South America, and subsequently been introduced to West Africa. No records appear to exist for P. megakarya outside West Africa and the only 
host on which it has been recorded is cocoa. The capacity of $P$. megakarya to cause root infections is equivocal. Gregory et al. (1984) considered that root infection maintained a reservoir of inoculum, allowing zoospores to be released into the soil surface water. From there, the zoospores were spread up the plant by small splash droplets in convection currents into the leaf canopy. On pods, the first macroscopic sign of infection is observed about 2 days after initial infection, and is manifested as a minute translucent spot on the pod surface. Insects, particularly the small black ant (Crematogaster striatula), are responsible for moving inoculum from the soil to the canopy (Evans, 1973). These ants also use old infected pods to construct tents around the pod peduncle, and this can lead to infection from the peduncle region.

Wet, showery conditions are essential for infection and spread. Wood (1974) has shown that long periods of relative humidity at saturation point are required for the rapid spread of disease. The theory that relative humidity is the most important climatic factor helps to explain the higher incidence in Nigeria than in Ghana, and the almost complete absence of black pod disease in Malaysia.Black pod disease of cocoa in West Africa, caused almost exclusively by P. megakarya, still remains one of the most serious constraints on cocoa production. Surveys during the 1978 and 1979 harvest season in Togo revealed losses of up to 80\%, when no control measures were taken (Djiekpor et al., 1981). Erwin and Ribeiro (1996) estimated a 20-30\% loss of the world's cocoa crop to black pod, and in some areas they estimated that $90-95 \%$ of the crop is rendered unusable. Symptoms in cocoa caused by $P$. megakarya can be easily confused with those caused by the three other species of Phytophthora which also cause black pod and include: P. palmivora, P. capsici and P. citrophthora. P. palmivora is the dominant species on cocoa in Nigeria and Cameroon (Gregory and Maddison, 1981; Zentmeyer, 1987).

Black pod caused by $P$. megakarya and $P$. palmivora can be distinguished because P. megakarya produces lesions with irregular edges on the fruit whereas lesions caused by P. palmivora have regular borders and are generally smaller (Erwin and Ribeiro, 1996). Pods are susceptible at all stages of development and may be infected at any place on the surface. The first symptom is a brown to black spot on the pod, which spreads rapidly in all directions and eventually covers the whole pod. The beans become infected internally about 15 days after the initial infection and are soon of no commercial value.

Generally, pods closest to the ground are first infected, with the disease rapidly spreading to affect fruit on the entire tree. P. megakarya can also cause seedling blight and trunk cankers (Zentmeyer, 1987), but its capacity to cause root rot is equivocal. Luz and Mitchell (1994) reported that even at high inoculum levels $P$. megakarya caused little damage to roots and no seedling mortality. Despreaux et al. (1987) also indicated that $P$. megakarya is not pathogenic to cocoa roots. Gregory et al. (1984), however, stated that P. megakarya is primarily a root-infecting pathogen.

Most synthetic fungicides used for the management and control of cocoa black pod infections contaminate stored foods commodity, leaving behind harmful residues, especially when application dosages are not properly followed (Dennis et al., 1994). Some exhibit phytotoxic effects on cocoa trees while in some, antimicrobial resistance may occur swiftly following repeated use. Bio magnification of some fungicides has also been reported by some workers. These shortcomings have led to loss of economic value on the produce as well as less acceptance from partner nations of the produce (Evans et al., 1971). In order to circumvent these constraints, farmer must resort to more proactive, sustainable and environmentally friendly means of controlling and managing the disease caused by Phytophthora megakarya. The potency of Chromolaena odorata (Akintola) to control Phytophthora megakarya infection of cocoa pods as claimed by some local farmers is being investigated as an alternative environmentally acceptable biological control method.

The study covers the isolation of Phytophthora megakarya from the lesions of infected cocoa pod with concomitant determination of its susceptibility (using agar-well diffusion method) to varying amounts of extracts of Chromolaena odorata (Akintola) in comparison with a selected synthetic fungicide as the positive control. The specific objective of this study are to; isolate Phytophthora megakarya from the lesions of infected cocoa pods; determine its susceptibility to varying extracts of Chromolaena odorata (Akintola); compare the antifungal potencies of these extracts with a selected synthetic fungicide and determine the minimum inhibitory concentration (MIC) of the various extracts at various concentrations.

\section{Materials and Methods}

\subsection{Media preparation}

Medium used during the process of experiment was Difco product of Potato Dextrose Agar supplemented with streptomycin (PDA for selective isolation of phytophthora megakarya), the medium for isolation of Phytophthora was prepared by strictly following the manufacturer instructions and all the steps taken during the process of medium preparation were subjected to aseptic condition (sterile environment). 
2.2. Collection of samples for the isolation of Phytophthora megakarya

Samples of infected cocoa pods were ramdomly selected from a cocoa plantation in Igodan community, Okitipupa local government area of Ondo state, and transported to Ondo State University of Science and Technology (Osustech) Microbiology Laboratory under aseptic condition. Scraps of lesions was aseptically and directly plated onto already prepared solid PDA.

\subsection{Media and antibiotics for the isolation of Phytophthora from diseased plant tissue and soil}

The Oomycetes are not true fungi, and therefore special techniques are required for their isolation. Most species of Phytophthora grow rather slowly in vitro compared with saprophytic fungi and bacteria. In addition, bacterial populations need to be kept low because they may suppress the growth of Phytophthora by direct competition, and antagonism caused by antibiotic production, or by direct parasitism. The use of selective media usually overcomes these problems. Antibiotics are added to isolation media in order to suppress the growth of bacteria.

\subsection{Antibiotic stock solution preparation}

Stock solution of the antibiotic was firstly prepared, by dissolving $500 \mathrm{mg}$ of streptomycin powder in $10 \mathrm{ml}$ of sterile injection water, and then allowed to dissolve appropriately. The unused stock solution for antibiotic was stored at $-4^{\circ} \mathrm{C}$.

\subsection{Preparation of plant extracts and inoculum}

Chromolaena odorata leaves were harvested at OSUSTECH farm, they were carefully washed in sterile distilled water, exactly $150 \mathrm{~g}$ was weighed using weighing balance and subsequently blended with the use of electric blender, the resulting mash was then steeped in 1 litre of the three solvents used for the extraction (i.e ethanol, cold-water and warm -water) and then allowed to stand at room temperature for 24 hours. The resulting solution was subsequently diluted and was then subjected to different concentrations. A $48 \mathrm{~h}$ fungal cultures (isolated from infected cocoa pods) grown on selective PDA at room temperature were used for the test.

\subsection{Antifungal activity screening test}

The antifungal activity of aqeous ethanol extracts, cold-water and warm-water extract of Chromolaena odorata against the fungal isolate was screened by using the agar-well diffusion method. Approximately $3 \mathrm{ml}$ of the antibiotic (streptomycin) prepared as described above was aseptically dispensed into PDA medium after it has been allowed to cool to $55^{\circ} \mathrm{C}$, the liquid medium was then poured onto sterile petri dishes and allowed to gel. Isolated pure culture of Phytophthora megakarya was used for the inoculation of the gelled medium. Sterile cork borer was used to make a well on each of the plates. $1 \%, 2 \%, 3 \%, 4 \%$ and $5 \%$ of each extracts was introduced into each well made on the medium, the plates were allowed to stand for 15 minutes in order to allow for proper diffusion of the extract into the medium before incubation. The plates were incubated at room temperature for about three days and the resulting inhibition zones were measure and recorded in millimeters $(\mathrm{mm})$.

\subsection{Determination of minimum inhibitory concentration}

The initial concentration of the plant extract $(100 \mathrm{mg} / \mathrm{ml}$ from $150 \mathrm{~g}$ into $1000 \mathrm{ml})$ was diluted using double fold serial dilution by transferring $5 \mathrm{ml}$ of the sterile plant extract (stock solution) into $5 \mathrm{ml}$ of sterile Nutrient broth to obtain $50 \mathrm{mg} / \mathrm{ml}$ concentration. The above process was repeated several times to obtain other dilutions: 25 , 12.5, 6.25, and $3.125 \mathrm{mg} / \mathrm{ml}$ (Rasooli and Abyaneh, 2004). Having obtained the different concentrations of the extracts, each concentration was inoculated with $0.1 \mathrm{ml}$ of the standardized spore suspension and incubation was done at $30^{\circ} \mathrm{C}$ for $72 \mathrm{~h}$. The growth of the inoculum in the broth is indicated by turbidity or cloudiness of the broth and the lowest concentration of the extract which inhibited the growth of the test organism were taken as the MIC (Jeff-Agboola and Onifade, 2016).

\subsection{Phytochemical screening}

Phytochemical examinations were carried out for all the extracts according to standard methods (Harborne, 1973; Odebiyi and Sofowora, 1978; Onwukeame, Ikuegbvweha and Asonye, 2007; Sofowora, 1982).

\subsubsection{Detection of tannins}

To the extract, $1 \%$ gelatin solution containing sodium chloride was added. Formation of white precipitate indicates the presence of tannins. 
2.8.2. Detection of flavonoids

Extracts were treated with few drops of sodium hydroxide solution. Formation of intense yellow colour, which becomes colourless on addition of dilute acid, indicates the presence of flavonoids.

\subsubsection{Detection of glycosides}

Extract was mixed with $2 \mathrm{ml}$ of glacial acetic acid containing 2 drops of $2 \% \mathrm{FeCl} 3$. The $\mathrm{m}$ ixture was poured into another tube containing $2 \mathrm{ml}$ of concentrated sulfuric acid. A brown ring at the interphase indicates the presence of glycosides.

\subsubsection{Detection of saponins}

Extracts were diluted with distilled water to $20 \mathrm{ml}$ and this was shaken in a graduated cylinder for $15 \mathrm{~min}$. Formation of $1 \mathrm{~cm}$ layer of foam indicates the presence of saponins.

\section{Results}

The results of the antifungal assay of the plant extract indicated that this plant exhibits antifungal activity against Phytophthora megakarya at different time interval. The result obtained in antifungal testing of the plant extract shows that the effectiveness of the plant extract varies with time and concentration of extracts. The results obtained from Agar-well diffusion method for warm-water extract showed that, warm water extract of this plant exhibited no inhibitory effect $(0.00 \mathrm{~mm})$ on the test fungus (Phytophthora megakarya) while the phytochemical analysis of warm-water extract revealed the absence of saponin and amino acid. In contrast phenol was tested positive with very high level, flavonoid and Glucosinulate were also tested positive but with low level, tannin was also detected at extremely low level for warm-water extract of Chromolaena odorata.

The results (Table 1) obtained from Agar-well diffusion method for ethanolic, warm and cold water extracts showed inhibitory effect at $1 \%, 2 \%, 3 \%, 4 \%$, and $5 \%$ concentration with diammeter zones of clearance of 15.00 $\mathrm{mm}, 16.00 \mathrm{~mm}, 18.00 \mathrm{~mm}, 21.00 \mathrm{~mm}$ and $32.00 \mathrm{~mm}$ respectively for ethanolic extract and 5.00, 15.00, 18.00, 20.00 and 30.00 respectively for cold water while warm water has no zone of clearance for all concentrations. The negative control using sterile distilled water showed no inhibitory effect on Phytophthora megakarya while $41.00 \mathrm{~mm}$ zone of clearance was observed in the positive control test using Metalaxyl and cuprous oxidecontaining synthetic fungicide as shown in Table 2.

Table 1. Potency of Chromolaena odorata extracts against $P$. megakarya.

\begin{tabular}{llll}
\hline Concentrations (\%) & \multicolumn{3}{c}{ Diameter of zones of clearance (MM) } \\
\cline { 2 - 4 } & Ethanolic extract & Cold water extract & Warm water extract \\
\hline $1 \%$ & $15.00^{\mathrm{a}}$ & $5.00^{\mathrm{b}}$ & 0.00 \\
$2 \%$ & $16.00^{\mathrm{a}}$ & $15.00^{\mathrm{a}}$ & 0.00 \\
$3 \%$ & $18.00^{\mathrm{a}}$ & $18.00^{\mathrm{a}}$ & 0.00 \\
$4 \%$ & $21.00^{\mathrm{a}}$ & $20.00^{\mathrm{a}}$ & 0.00 \\
$5 \%$ & $32.00^{\mathrm{b}}$ & $30.00^{\mathrm{a}}$ & 0.00 \\
\hline
\end{tabular}

${ }^{\mathrm{ab}}$ Values are means of three replicates determinations; SEM = Standard error of mean. Means with different superscripts in a row are significantly different $(\mathrm{P}<0.05)$

Table 2. Results for control test.

\begin{tabular}{lll}
\hline Parameters & Concentrations & Diameter of zone of clearance (mm) \\
\hline Negative Control (70\%) & $0.2 \mathrm{ml}$ sterile distilled water & 0.00 \\
Positive control (synthetic fungicide/ red-force) & $5 \mathrm{mg}$ & 41.00 \\
\hline
\end{tabular}

Table 3. Result for minimum inhibitory concentration.

\begin{tabular}{llll}
\hline Concentrations $(\mathbf{m g} / \mathbf{m l})$ & Cold-water extract & Ethanolic extract & Warm-water extract \\
\hline 50.00 & - & - & + \\
25.00 & - & - & + \\
12.50 & - & + & + \\
6.25 & + & + & + \\
3.123 & + & + & + \\
\hline
\end{tabular}

(+) turbidity, ( -) no turbidity 
Table 4. Active ingredients tested in extracts of Chromolaena odorata.

\begin{tabular}{llll}
\hline Active agents & Cold-water extract & Warm-water extract & Ethanolic extract \\
\hline Saponin & + & - & + \\
Tannin & + & + & + \\
Phenol & + & + & + \\
Flavonoid & + & + & + \\
Glucosinolate & + & + & + \\
Amino acid test & + & - & - \\
\hline
\end{tabular}

$(+)=$ Positive $\quad(-)=$ Negative

Phytochemical screening revealed the presence of saponin, tannin, phenol, flavonoid and glucosinulate, while amino acid was tested negative for aqeous ethanol extract of Chromolaena odorata. Results obtained from Agar-well diffusion for cold-water extract showed high degree of antifungal activity at various concentrations used. All the biologically active agents were tested positive for cold-water extract which include saponin, phenol, glucosinulate, flavonoid, and amino acid. The concentrations used were prepared from the initial stock solution of extracts containing $150 \mathrm{~g} / \mathrm{l}$ of distilled water. The results obtained on the minimum inhibitory concentration (Table 3) show that $50 \mathrm{mg} / \mathrm{ml}$ and $25 \mathrm{mg} / \mathrm{ml}$ of cold water extract of Chromolaena odorata had fungicidal effect against Phytophthorame gakarya. The results indicated that among the tested concentrations of cold water extract, there was a significant difference. On the other hand, extract of warm-water had neither fungicidal nor fungistatic effect against the test organism. Ethanolic extract also showed significant level of fungicidal activity at $50 \mathrm{mg} / \mathrm{ml}$ and $25 \mathrm{mg} / \mathrm{ml}$.

The results obtained from phytochemical screening show that, tannin, phenol, flavonoid and glucosinulate were present in all the extracts irrespective of the method of extraction adopted. Amino acid was absent for both ethanolic and warm-water extract, whereas all the five biologically active agents screened tested positive for cold water extract. The warm-water extraction method might have influenced the absence of saponin as this active agent was also tested negative for in warm-water extracts.

\section{Discussion}

Table 1 clearly show that, Phytophthora megakarya exhibits varying degree of susceptibility to extract of Chromolaena odorata at various concentrations using cold water and ethanol as the extract compared to warm water extract in which no susceptibility was seen. Investigators in the past had also clearly shown that ethanolic extracts and cold-water extracts were more effective than warm-water extract (Bakht et al., 2011). They have attributed this observation to the high volatility of ethanol which tends to extract more active compound from the sample than warm-water, which tends to have negative effect on amino acid properties and saponin. Hence, these studies followed similar trends. The efficiency of the antifungal activity of the extracts was enhanced by increase in the concentration of the extracts. This finding agrees with the report of Mares et al. (2004) that higher concentration of antimicrobial substance showed appreciation in growth inhibition.

The minimum inhibitory concentration values (Table 3 ) of the plant extracts against the test organism showed that fungi vary widely in the degree of their susceptibility to antifungal agents. Several reports stated that the extracts of medicinal plants play an important role in controlling many phytopathogenic fungi (Abd-El-Khair and Haggag, 2007; Choi et al., 2004; Lin, Zon, Lin and Tan, 2001; Okemo, Bias and Vivanco, 2003; PerezSanchez et al., 2007). Results obtained from phytochemical screening of the extract (Table 4) showed that, the inhibitory effect of Chromolaena odorata plant might be due to the presence of steroids, terpenoids, alkaloids, flavonoids, glucosinulate, amino acid, tannins, phenolic compounds and saponins. In recent years much research has been conducted in the field of antifungal effects of different plants. In the present, investigation, the antifungal activity of the plant extracts was assayed against Phytophthora megakarya at different time interval and with different concentrations of extracts to understand the most effective concentration. Several workers have made similar observations by testing the antifungal activity of the extract or complex mixture from higher plants against some filamentous fungi, unicellular fungi and moulds (Gonzalez-Lamothe et al., 2009). Some medicinal plants have higher antifungal properties and higher diffusion power (Gonzalez-Lamothe et al., 2009). The fact that the results of this study showed that plants extracts exhibited antifungal properties justifies their traditional use as medicinal plants. This may be due to the presence of active agents in the plant materials. Plants generally produce many secondary metabolites which constitute an important source of microbicides, pesticides and many pharmaceutical drugs (de Billerbeck et al., 2001). Plant products still remain the principal source of pharmaceutical agents used in orthodox medicine. 


\section{Conclusions}

These findings suggest a new pathway in elucidating a potent antifungal agent from plant like Chromolaena odorata. This study indicates that the plant contains antifungal compound that can be further developed as phytomedicine for the therapy of infection (Jeff-Agboola et al., 2012). Such screening of various natural organic compounds and identification of active agents is the need of the hour because, this can effectively address the residual effects seen with the use of synthetic fungicides for the control and management of infections caused by the test fungus. In conclusion, the action of extracts upon the antifungal models justified its usefulness in herbal formulation. In conclusion, the results obtained from this study show that the plants extracts used in this study exhibit antifungal activities against Phytophthora megakarya. Extracts of the plant used in this study could be useful in the treatment of fungal infections caused by Phytophthora megakarya.

\section{Conflict of interest}

None to declare.

\section{References}

Abd-El-Khair H and WM Haggag, 2007. Application of some Egyptian medicinal plant extracts against potato late and early blights. Research Journal of Agriculture and Biological Sciences, 3: 66-175.

Aryantha IP, R Cross and DI Guest, 2000. Suppression of Phytophthora cinnamomi in potting mixes amended with uncomposed animals manures. Phytopathology, 90: 775-782.

Bakht J, M Tayyab, H Ali, A Islam and M Shafi, 2011. Effect of different solvent extracted sample of Allium sativum (Linn) on bacteria and fungi. Afr. J. Biotechnol., 10: 5910-5915.

Bowers JH, BA Bailey, PK Hebbar, S Sanogo and RD Lumsden, 2001. The impact of plant disease on world chocolate production.

Brasier CM, 1983. Problems and prospects in Phytophthora research .In Phytophthora: its biology, taxonomy, ecology and pathology, edited by D. C. Erwin, Bartnicki-Garcia, and P.H. Tsao. St. Paul, Minnesota, USA: American P Phytopathological Society.

Cavalier-Smith T, 1986. The kingdom Chromista: origin and systematics. In Progress in phycological research, edited by I. Round and D.J. Chapman, Bristol, England: Biopress.

Choi GJ, KS Jang, JS Kim, SW Lee, JY Cho, KY Cho and JC Kim, 2004. In vivo antifungal activities of 57 plant extracts against six plant pathogenic fungi. The Plant Pathology Journal, 20: 184-191.

de Billerbeck VG, CG Roques, JM Bessière, JL Fonvieille and R Dargent, 2001. Effects of cymbopogon nardus (L.) W. Watson essential oil on the growth and morphogenesis of Aspergillus niger. Can. J. Microbiol., 47: 9-17.

Dakwa JT, 1973. The relationship between black pod incidence and the weather in Ghana. J. Agric. Sci., 6: 93102.

Dennis JJC and JK Konam, 1994. Phythophthora palmivora cultural control methods and their relationship to disease epidemiology on cocoa in Papua New Guinea. $11^{\text {th }}$ International Cocoa Reseach Conference. Cocoa Producer Alliance. 11 (953-957).

Desjardins PR, GA Zentmeyer and DA Reynolds, 1969. Electron microscopic observations of the flagellar hairs of Phytophthora palmivora zoospores. Can. J. Bot., 47: 1077-1079.

Eckert JW, 1962. A selective antibiotic medium for isolation of Phytophthora and Pythium from plant roots. Phytopathology, 52: 771-777.

Efombagn MIB, S Nyasse, O Sounigo, M Kolesnika-Allen and AB Eskes, 2007. Participatory cocoa selection in Cameroon: phytophthora pod rot resistant accessions identified in farmers' field. Crop Prot., 26: 14671473.

Elliott CG, 1983. Physiology of sexual reproduction in Phytophthora. In Phytophthora: Its biology, taxonomy, ecology and pathology, edited by D. C. Erwin, S. Bartnicki-Garcia, and P.H. Tsao. St. Paul, Minnesota, USA: American Phytopathological Society.

Erwin DC and OK Ribeiro, 1996. Phytophthora diseases worldwide. St. Paul, Minnesota: APS Press.

Evans HC, 1981. Transmission of Phytophthora pod rot of cocoa by Invertebrates. Nature, 232 : 346-719.

Gonzalez-Lamothe R, G Mitchell, M Gattuso, SM Diarra, F Malouin and K Bouarab, 2009. Plant antifungal agents and their effects on plant and human pathogens. Int. J. Mol. Sci., 10: 3400-3419.

Gregory PH, MJ Griffin, AC Maddison and MR Ward, 1984. Cocoa black pod: a reinterpretation. Cocoa Growers' Bulletin, No. 35:5-22

Guest D, 2007. Black pod: Diverse pathogens with a global impact on cocoa yield. Phytopathology, 97: 16501653. 
Gunasekera L, 2009. Invasive plants: a guide to the identification of the most invasive plants in Sri Lanka. Colombo. 116-117.

Hanada RE, TJ Souza, AWV Pomella, A Ismaiel and GJ Samuels, 2008. Trichoderma martiale sp. Nov., a new endophyte from sapwood of Theobroma cacao with a potential for biological control. Mycol. Res., 112: $1335-1343$.

Jeff-Agboola YA, AK Onifade, BJ Akinyele and IB Osho, 2012. In vitro antifungal activities of essential oil from Nigerian Medicinal Plants against toxigenic Aspergillus flavus. Journal of Medicinal Plants Research, 6: 4048-4056.

Konam JK and DI Guest, 2002. Leaf litter mulch reduces the survival of phythophthora to palmivora under cocoa trees in Papua New Guinea. Plant Pathol., 31: 381- 383.

Lin CH, WX Zon, H Lin and RX Tan, 2001. Antifungal activity of Artemisia annuaendophytic cultures against phytopathogenic fungi. Journal of Biotechnology, 88: 277-282.

Luseni MM and S Kroma, 2012. Black pod disease of coacoa (PDF)

Luz EDMN and DJ Mitchell, 1994. Effects of inoculum forms and densities on cocoa root infection by Phytophthora spp. Agrotropica, 6: 41-51.

Okemo PO, HP Bais and JM Vivanco, 2003. In vitro activities of Maesa lanceolata extracts against fungal plant pathogens. Fitoterapia, 74: 312-316.

Opoku IY, AA Appiah, AY Akrofi and GK Owusu, 2000. "Phytophthora megakarya: A potential threat to the cocoa industry in Ghana". Ghana Journal of Agricultural Science, 33: 237-248.

Perez-Sanchez R, F Infante, C Galvez and JL Ubera, 2007. Fungitoxic activity against phytopathogenicfungi and the chemical composition of Thymus zygis essential oil. Food Science and Technology International, 13: 341-347.

Philip-Mora, Wilbert and Rolando Cerda, 2009. Catalog: Cocoa Diseases in Central America. Tropical Agricultural Reseach and Higher Education Centre, CATIE. Retrieved 20 November 2013.

Taylor B and M J Griffin, 1981. The role and importance of different ant species in the dissemination of black pod disease of cocoa. Epidemiology of phytophthora on Coacoa in Nigeria. UK: Commonwealth Mycological Institute, Kew. pp. 144-131.

U. S. Bureeau of Census, 2010. Current Industrial Reports: MA311D- Confectionery Wood, G. A. R. (1974). Cocoa. London, UK: Longman.

Zentmyer GA, 1980. Phytophthora cinnamomi and the diseases it causes, Monograph No. 10. St. Paul, Minnesota, USA: American Phytopathological Society.

Zentmyer GA, JD Gilpatrick and WA Thorn, 1960. Methods of isolating Phytophthora cinnamomi from soil and from host tissue. Phytopathology, 50: 87. 